\title{
Principles of Protection in Warfare under International Humanitarian Law
}

\subsection{Introduction}

The aim of this chapter is to analyse from a positivist perspective the principles of protection under the IHL regime. In this regard, this chapter will adopt a similar structure as the one presented in Chapter I where the principles of protection under ILW were examined. In this chapter, the principles of distinction and proportionality as applied in the different jurisdictional regimes of international and non-international armed conflict will be looked upon. Both primary sources, i.e. treaties, customs and other general principles, as well as secondary, i.e. (inter)national jurisprudence and legal doctrines, will be used to determine those protective standards' evolution and application. This analysis is particularly important for Part III, in Chapter VI, where this positivist account will be juxtaposed with the historical analysis as examined in Part II, in Chapter III. It will be submitted that the narrative on the "Western" Self and its Other have influenced the interpretation and application of the rules of armed conflict. Moreover, determining these universal principles of protection will assist a future reading on the structure of the legal arguments in IHL considerably. The chapter will firstly deal with the territorial and temporal jurisdiction, secondly with the principle of distinction and thirdly with the principle of proportionality.

Before beginning with the above-mentioned, some explanation on the sources of IHL is necessary. The codified branch of IHL consists of the so-called 1899-1907 Hague Regulations ${ }^{1}$ and 1949 Geneva Conventions. ${ }^{2}$ The former limit

11899 Final Act of the International Peace Conference, 1899 Convention with Respect to the Laws and Customs of War on Land and its Annex: Regulations concerning the Laws and Customs of War on Land (1899 Hague II), 1899 Convention for the Adaptation to Maritime Warfare of the Principles of the Geneva Convention of 22 August 1864 (1899 Hague III), 1899 Declaration to Prohibit, for the Term of Five Years, the Launching of Projectiles and Explosives from Balloons, and Other Methods of Similar Nature (1899 Hague IV, 1), 1899 Declaration concerning Asphyxiating Gases (1899 Hague IV, 2), 1899 Declaration concerning Expanding Bullets (1899 Hague IV, 3), 1907 Final Act of the Second Peace Conference, 1907 Convention respecting the Laws and Customs of War on Land and its Annex: Regulations concerning the Laws and Customs of War on Land 1907 (1907 Hague IV), 1907 Convention relative to the 
or prohibit the means and methods of warfare whereas the latter protect the victims of war, i.e. non-combatants and persons no longer taking direct part in the armed hostilities. The 1977 Additional Protocols ${ }^{3}$ to the 1949 Geneva Conventions provide a more detailed account on the principles of protection as applicable both during international and non-international armed conflicts. A great number of those limitations on warfare and on the protection of victims have become customary international law or even peremptory norms and conversely many customary rules have been codified as well. These customary rules have been listed in the customary law study on IHL as commissioned by the International Committee of the Red Cross (ICRC). ${ }^{4}$ Also weapons conventions ${ }^{5}$ contribute to these ends and will be referred to where necessary.

Laying of Automatic Submarine Contact Mines (1907 Hague VIII), 1907 Convention concerning Bombardment by Naval Forces in Time of War (1907 Hague IX), 1907 Convention for the Adaptation to Maritime Warfare of the Principles of the Geneva Convention (1907 Hague X), 1907 Declaration Prohibiting the Discharge of Projectiles and Explosives from Balloons (1907 Hague XIV).

21949 Convention for the Amelioration of the Condition of the Wounded and Sick in Armed Forces in the Field (GC I), 1949 Convention for the Amelioration of the Condition of Wounded, Sick and Shipwrecked Members of Armed Forces at Sea (GC II), 1949 Convention relative to the Treatment of Prisoners of War (GC III), 1949 Convention relative to the Protection of Civilian Persons in Time of War (GC IV).

31977 Protocol Additional to the Geneva Conventions of 12 August 1949, and relating to the Protection of Victims of International Armed Conflicts (AP I), 1977 Protocol Additional to the Geneva Conventions of 12 August 1949, and relating to the Protection of Victims of NonInternational Armed Conflicts (AP II).

4 See Jean-Marie Henckaerts \& Louise Doswald-Beck, Customary international humanitarian law (Cambridge University Press 2005).

51925 Protocol for the Prohibition of the Use of Asphyxiating, Poisonous or Other Gases, and of Bacteriological Methods of Warfare, 1972 Convention on the Prohibition of the Development, Production and Stockpiling of Bacteriological (Biological) and Toxin Weapons and on their Destruction, 1980 Convention on Prohibitions or Restrictions on the Use of Certain Conventional Weapons Which May be Deemed to be Excessively Injurious or to Have Indiscriminate Effects, 1980 Protocol on Non-Detectable Fragments (Protocol I), 1980 Protocol on Prohibitions or Restrictions on the Use of Mines, Booby-Traps and Other Devices (Protocol II), 1980 Protocol on Prohibitions or Restrictions on the Use of Incendiary Weapons (Protocol III), 1993 Convention on the Prohibition of the Development, Production, Stockpiling and Use of Chemical Weapons and on their Destruction, 1995 Protocol on Blinding Laser Weapons (Protocol IV), 1996 Amended Protocol on Prohibitions or Restrictions on the Use of Mines, Booby-Traps and Other Devices, 1997 Convention on the Prohibition of the Use, Stockpiling, Production and Transfer of Anti-Personnel Mines and on their Destruction, 2003 Protocol on Explosive Remnants of War (Protocol V), 2008 Convention on Cluster Munitions. 
In addition, as this chapter will demonstrate, (inter)national jurisprudence ${ }^{6}$ on the principles of protection and on the different jurisdictional regimes has further elucidated on their interpretation and application in several cases and has denounced their difficulties as well as their potentials to reconcile jus ad bellum, i.e. the law on the use of force, and human rights law with the jus in bello, i.e. IHL.

\section{Territorial and Temporal Jurisdiction}

\subsubsection{On the Fragmentation of International (Humanitarian) Law}

The aims of international law to restrict the use of force on the international arena, i.e. jus ad bellum, and those of IHL to regulate the conduct of warfare among the warring parties, i.e. jus in bello, have to be seen in close relationship. ${ }^{7}$ The idealist enterprise to enhance peace among nations and the so-called "human necessity" 8 to provide protection in case of violation of peace are not necessarily paradoxical but are intertwined. In this respect, as stipulated in the Preamble of 1899 Hague II, "while seeking means to preserve peace and prevent armed conflicts among nations, it is likewise necessary to have regard to cases where an appeal to arms may be caused by events which their solicitude could not avert". ${ }^{9}$ From this realist perspective, if the ends to go to war would justify the means used during war, then certain means could make those ends beyond reach. ${ }^{10} \mathrm{~A}$ state might assert its sovereignty by attacking or defending itself but it has to give a normative justification in accordance with the existing international law on the use of force. With regard to this law on the use of force, different regimes existed before and after the 1928 KelloggBriand Pact and the 1945 UN Charter." Both the idealist and realist categories

6 In particular of the International Criminal Tribunal for the Former Yugoslavia (ICTY).

7 See Ryan Goodman, 'Controlling the recourse to war by modifying jus in bello', (2009) 12 Yearbook of International Humanitarian Law, 53; Robert D. Sloane, 'The costs of conflation: preserving the dualism of jus ad bellum and jus in bello in the contemporary law of war', (2009) 34 Yale Journal of International Law, 47.

Hilaire McCoubrey, International humanitarian law: modern developments in the limitation of warfare (Ashgate 1998), at 5 .

Preamble, 1899 Hague II; see also Preamble, 1907 Hague IV having substituted the 1899 Hague II and its Annex (i.e. Regulations respecting the Laws and Customs of War on Land).

Geoffrey Francis Andrew Best, War and law since 1945 (Oxford University Press 1994), at 244.

David Rodin, War and self-defense (Oxford University Press 2002), at 119-20. 
of asserting power are, however, often manipulated along both ends to justify states' behaviour. $^{12}$ In spite of the relativity of the moral claims on the use of force on the international plane, all parties to the conflict must, nevertheless, respect the same IHL. ${ }^{13}$ Hence, all combatants, whether lawful or unlawful, are morally equal before the laws of armed conflict. ${ }^{14}$

The use of force within non-international armed conflicts, however, is not regulated by international mechanisms as such. As the organs of the state have the sole prerogative to use force,$^{15}$ they would rather treat the use of force by non-state actors against the state as so-called "situations of internal disturbances and tensions", as put by Article 1(2) of AP II. In this respect, states would avoid these situations to be defined as non-international armed conflicts and would keep them outside the realm of IHL. Consequently, the application of IHL would depend on the recognition of the belligerent parties in internal armed conflicts. ${ }^{16}$ Although the rebels' cause is subject to domestic jurisdiction, Cassese finds that their "legal standing"17 also has an international aspect, in particular toward the international community and other states. In spite of this attempt to broaden the international protection of IHL within internal armed conflicts, the ICTY in its Tadić case stated that "(i) only a number of rules and principles governing international armed conflicts have gradually been extended to apply to internal conflicts; and (ii) this extension has not taken place in the form of a full and mechanical transplant of those rules to internal conflicts; rather, the general essence of those rules, and not the detailed regulation they may contain, has become applicable to internal

\footnotetext{
12 Id., at 195.

13 Marco Sassòli, 'Jus ad bellum and jus in bello: the separation between the legality of the use of force and humanitarian rules to be respected in warfare: crucial or outdated?' in Michael N. Schmitt \& Jelena Pejic (eds), International law and armed conflict: exploring the faultlines: essays in honour of Yoram Dinstein (Martinus Nijhoff Publishers 2007), at 246; Hortensia D.T. Gutierrez Posse, 'The relationship between international humanitarian law and the international criminal tribunals', (2006) 88 International Review of the Red Cross, 65 , at 79 .

14 Jeff McMahan, Killing in war (Oxford University Press 2009), at 4.

15 Sassòli, in, at 255 .

16 Hans Kelsen, 'Recognition in international law: theoretical observations', (1941) 35 American Journal of International Law, 605, at 617; see also Sylvain Vité, 'Typology of armed conflicts in international humanitarian law: legal concepts and actual situations', (2009) 91 International Review of the Red Cross, 69 .

17 Antonio Cassese, 'Status of rebels under the 1977 Geneva Protocol on non-international armed conflict', (1981) 30 International and Comparative Law Quarterly, 416, at 429.
} 
conflicts". ${ }^{18}$ However, so-called wars of national liberation for the right of selfdetermination by the colonial peoples against the colonial powers are also considered to be justified by the international law on the use of force. ${ }^{19}$ These wars of national liberation would become subjected to the laws of armed conflict under AP I and would no longer be considered to be non-international armed conflicts. ${ }^{20}$ Here again, given its interconnection, grounds under the jus ad bellum would allow such conflict to become internationalised under the jus in bello.

Despite the legal characterisation of different armed conflicts, state practices would seem to demonstrate certain uniformity in applying IHL. Such state practice would seem to make different regulations for both international and non-international armed conflicts undesirable. ${ }^{21}$ Nonetheless, during the Global War on Terror, the indeterminacy of the conflict would appear to undermine the application of IHL to take place. Hence, as noted by Quénivet, international jurisprudence would help "in appraising whether an armed conflict is, in fact, taking place". ${ }^{22}$ For example, in the Tadic case, the ICTY's Appeals Chamber specified that "an armed conflict exists whenever there is a resort to armed force between States or protracted armed violence between governmental authorities and organised armed groups or between such groups within a State. ${ }^{23}$ In stating so, the Tribunal blurred the legal distinction between both types of conflict for so-called "compelling humanitarian reasons". ${ }^{24}$ Nonetheless, this compartmentalisation between the two distinct

18 Prosecutor v. Tadić, ICTY, Appeals Chamber, Decision on the Defence Motion for Interlocutory Appeal on Jurisdiction, 2 October 1995, Case No. IT-94-1-AR72, at www.icty .org, para. 126. (Last accessed on 15 February 2015)

19 Elisabeth Chadwick, Self-determination, terrorism and the international humanitarian law of armed conflict (Martinus Nijhoff Publishers 1996), at 9.

20 Article 1(4), AP I.

21 Emily Crawford, 'Unequal before the law: the case for the elimination of the distinction between international and non-international armed conflicts', (2007) 20 Leiden Journal of International Law, 441, at 457 .

22 Noëlle Quénivet, "The applicability of international humanitarian law to situations of a (counter-)terrorist nature', in Roberta Arnold (ed), International humanitarian law and the 21st century's conflicts: changes and challenges (Editions universitaires suisses 2005), at 33 .

23 Prosecutor v. Tadić, ICTY, Appeals Chamber, Decision on the Defence Motion for Interlocutory Appeal on Jurisdiction, 2 October 1995, Case No. IT-94-1-AR72, at www.icty .org, para. 70. (Last accessed on 15 February 2015)

24 Crawford, at 443. 
laws of armed conflict prevents "the principle of natural justice", ${ }^{25}$ as understood by Cryer, and thus equality as described by Hart to "secure that the law is applied to all those and only those who are alike in the relevant respect marked out by the law itself". ${ }^{26}$ How could different jurisdictional regimes ever do justice to the victims of war?

Also, peremptory norms of IHL and human rights law would further advance the basic humanitarian considerations during peacetime and wartime. In spite of their protective measures respectively during wartime and peacetime, the discrepancy between those legal regimes of international armed conflict and non-international armed conflict ${ }^{27}$ has also tried to divide IHL, i.e. lex specialis, and human rights law, i.e. lex generalis. ${ }^{28}$ This unnecessary dichotomy has been criticised by Best in the following words:

The idea of humankind upon which it is founded is, after all, an even bolder one than that of human rights law, its twin in this matter. IHL and human rights law, proclaiming the same truth, sing from different scores. The human rights score, on the sunnier side, proclaims that humankind, for all its admitted subspecies diversity and notwithstanding the red herrings of cultural relativism, is one moral community and that its individual members, from whatever part of it they come, can respond to that community's demands and normally wish to do so. The IHL score in more sombre tones, perceiving that the groups composing that community continue to get into deadly quarrels with one another, prudently prescribes rules for their conduct and punishments for breaking them. ${ }^{29}$

Clearly, the fragmentation of the laws on the use of force and the laws of armed conflict would seem to be artificial in the sense that their interconnection is manifestly present when it comes to determining legitimate belligerency and the applicable law during armed conflict. Though the separation of IHL from human rights law appears to be more justifiable, the protection that victims

25 Robert Cryer, Prosecuting international crimes: selectivity and the international criminal law regime (Cambridge University Press 2005), at 195.

26 Herbert L.A. Hart, The concept of law (Clarendon 1994), at 160.

27 Heather A. Wilson, International law and the use of force by national liberation movements (Clarendon Press 1988), at 34.

28 Ingrid Detter De Lupis, The law of war (Cambridge University Press 1987), at 131; see also Jorge Cardona Llorens, 'Libération ou occupation? Les droits et devoirs de l'état vainqueur', in Karine Bannelier (ed), Lintervention en Irak et le droit international (Pedone 2004), at 234 .

29 Best, at 293 . 
of war deserve might go beyond the actual wartime and peacetime. ${ }^{30}$ Still, the current legal paradigm makes these divisions and, therefore, the next sections will, firstly, determine the rules on the different jurisdictional regimes of international and non-international armed conflict both territorially and temporally (in a chronological order in terms of the date of the creation of the different sources of IHL); secondly, analyse how the principles of distinction and proportionality operate within those different jurisdictional regimes.

\subsubsection{International Armed Conflicts}

\subsubsection{Territorial Jurisdiction}

From the territorial perspective, the laws of international armed conflict and occupation start to apply, according to the 1899-1907 Hague Regulations, whenever the territory "is actually placed under the authority of the hostile army". ${ }^{31}$ Common Article 2 of the 1949 Geneva Conventions stipulates that the "partial or total occupation of the territory of a High Contracting Party" brings about their application. Article 1(3) of AP I confirms its application with reference to common Article 2 of the 1949 Geneva Conventions. In practice, a lot of ambiguity remains as to when the belligerent occupation commences. Most

30 For more on the discussion on the relationship between IHL and human rights law, see Robert Cryer, 'The interplay of human rights and humanitarian law: the approach of the ICTY', (2009) 14 Journal of Conflict and Security Law, 511; Christopher Greenwood, 'Human rights and humanitarian law: conflict or convergence', (2010) 43 Case Western Reserve Journal of International Law, 491; Hans-Joachim Heintze, 'On the relationship between human rights law protection and international humanitarian law', (2004) 86 International Review of the Red Cross, 789; Jean-Marie Henckaerts, 'Concurrent application of international human rights law and international humanitarian law: victims in search of a forum', (2007) 1 Human Rights and International Legal Discourse, 95; Robert McLaughlin, 'The law of armed conflict and international human rights law: some paradigmatic differences and operational implications', (2010) 13 Yearbook of International Humanitarian Law, 213; Alexander Orakhelashvili, 'The interaction between human rights and humanitarian law: fragmentation, conflict, parallelism or convergence?', (2008) 19 European Journal of International Law, 161; Marco Sassòli \& Laura M. Olson, 'The relationship between international humanitarian and human rights law where it matters: admissible killing and internment of fighters in non-international armed conflicts', (2008) 90 International Review of the Red Cross, 599; Iain Scobbie, 'Principle or pragmatics? The relationship between human rights law and the law of armed conflict', (2009) 14 Journal of Conflict and Security Law, 449; Kenneth Watkin, 'Controlling the use of force: a role for human rights norms in contemporary armed conflict', (2004) 98 American Journal of International Law, 1.

Article 42, 1899 Hague II; Article 42, 1907 Hague IV. 
would agree that the control and thus the authority over a particular territory entail the respect for the laws of occupation. ${ }^{32}$

AP I introduced another ground for the use of force in the international arena ${ }^{33}$ whose conduct of hostilities is subjected to its own provisions and to those of the 1949 Geneva Conventions. In this regard, Article 1(4) of AP I includes "armed conflicts in which peoples are fighting against colonial domination and alien occupation and against racist regimes in the exercise of their right of self-determination, as enshrined in the Charter of the United Nations and the Declaration on Principles of International Law concerning Friendly Relations and Co-operation among States". These peoples fighting for their right of self-determination would be treated as other High Contracting Parties. They would have to assume the same treaty obligations as the High Contracting Parties upon the condition that the authorities representing their peoples, according to Article 96(3) of AP I, unilaterally declare to "apply the [1949 Geneva] Conventions and this Protocol in relation to that conflict". The armed forces of this party shall respect Article 43(1) of AP I and thus comply "with the rules of international law applicable in armed conflict". The interaction between jus ad bellum and jus in bello is obvious; respectively, the authority to declare compliance with IHL leads to the "recognition of belligerency" 34 whereas the latter's capacity is a requirement for "legitimate combatancy". 35 McCoubrey and White have argued that "although it may be strongly contended that, where an 'internationalized' international humanitarian regime is made applicable, the generality of 'Hague' norms should also be applied". 36 Clearly, the internationalisation of armed conflicts has an impact upon the applicability of a jurisdictional regime with a greater territorial scope.

In spite of these attempts to internationalise so-called wars of national liberation, to provide protections to victims of war and to impose limitations on the conduct of hostilities of all parties to such conflicts, their real scope would seem to be very limited. ${ }^{37}$ The decolonisation era as focused upon by Article 1(4) of AP I was almost completely finished at the moment AP I was adopted;

\footnotetext{
32 Hilaire McCoubrey \& Nigel D. White, International law and armed conflict (Dartmouth 1992), at 282-3.

33 Christopher Greenwood, Essays on war in international law (Cameron May 2007), at 215.

34 Wilson, at 48.

35 Id., at 48 .

$36 \quad$ McCoubrey \& White, International law and armed conflict, at 199.

37 See also Detlev F. Vagts \& Theodor Meron, 'The Geneva Conventions of 1949 and wars of national liberation', in Detlev F. Vagts, Theodor Meron, Stephen M. Schwebel \& Charles Keever (eds), Humanizing the laws of war: selected writings of Richard Baxter (Oxford University Press 2013), at 279.
} 
besides, the ratification of AP I by the member states of the international community took place predominantly after the Cold War-more than one decade later than its adoption. ${ }^{38}$ In addition, when considering the cumulative conditions of resistance "against colonial domination and alien occupation and against racist regimes", practically speaking and in a restrictive sense, only the past fight against the Apartheid regime in South Africa and Namibia could be aimed at. Moreover, when acknowledging the application of this Protocol to those limited armed conflicts, Article 96(3) stating that "the authority representing a people engaged against a High Contracting Party [...] may undertake to apply the Conventions and this Protocol" presumes that the compliance with the Geneva Conventions and AP I are two different obligations; whereas, AP I "supplements the Geneva Conventions"; 39 it cannot be dissociated from the latter; and thus supplements "in all circumstances". ${ }^{0}$

\subsubsection{Temporal Jurisdiction}

From the temporal point of view, armed conflicts between High Contracting Parties start traditionally by a declaration of war ${ }^{41}$ or by "an ultimatum with conditional declaration of war". ${ }^{2}$ AP I, as intended, supplements the situations as referred to in common Article 2 of the 1949 Geneva Conventions. ${ }^{43}$ Nowadays, declarations of war are in desuetude. ${ }^{44}$ In this regard, the Tadic definition of armed conflict as mentioned above is useful in determining when an international armed conflict actually commences and from which moment IHL is applicable, namely "whenever there is a resort to armed force between States". ${ }^{45}$ For wars of national liberation, according to Article 96(3) of AP I, from the moment of receipt of the declaration of the authority representing those peoples warring against their oppressors by the depositary, "the conventions

38 See website of the ICRC: ICRC, at http://www.icrc.org/IHL.nsf/\%28SPF\%29/party_main_ treaties/\$File/IHL_and_other_related_Treaties.pdf. (Last accessed 15 February 2015).

39 Article 1(3), AP I.

40 Article 1(1), AP I.

41 Article 1, 1907 Hague III; Common Article 2, GC I-IV.

42 Article 1, 1907 Hague III.

43 Article 3, AP I.

44 Christopher Greenwood, 'Scope of application of humanitarian law', in Dieter Fleck (ed), The handbook of international humanitarian law (Oxford University Press 2010), at 49.

45 Prosecutor v. Tadić, ICTY, Appeals Chamber, Decision on the Defence Motion for Interlocutory Appeal on Jurisdiction, 2 October 1995, Case No. IT-94-1-AR72, at www.icty .org, para. 70. (Last accessed on 15 February 2015) 
and this Protocol are equally binding upon all" ${ }^{16}$ High Contracting Parties to the internationalised armed conflict.

With respect to the conclusion of war and the application of relevant rules of IHL, such as belligerent occupation, international law has provided many mechanisms leading to the termination of war, such as cease-fire, truce and armistice, peace agreements, etc. ${ }^{47}$ It remains, however, difficult to assess the legal status of a territory whether it is "de jure occupied [or] de facto selfgoverning", as put by Alonzo-Maizlish..$^{48}$ Neither is it clear when control over those territories has to be handed over to the sovereign. ${ }^{49}$ Though, the scope of protection to civilians in the territories of the High Contracting Parties as guaranteed in Article 6 of GC IV continues beyond the actual "general close of military operations" or "in the case of occupied territory" beyond "one year after the general close of military operations". Thus, "protected persons whose release, repatriation or re-establishment may take place after such dates shall meanwhile continue to benefit by the present Convention".50 Article 5 of GC III provides a similar extended protection to prisoners of war. Article 3 of AP I somehow combines and confirms such protection for two protected categories of individuals, i.e. civilians and prisoners of war; it seemingly extends the protection not only after "the general close of military operations" but also beyond "the termination of the occupation".

\subsubsection{Non-International Armed Conflicts}

\subsubsection{Territorial Jurisdiction}

The fulfilment of the requirements of legal combatancy, paralleling those of the internationalised armed conflicts, ${ }^{51}$ imposed upon the rebel armed forces would be a sign of quasi-governmental authority, "albeit unrecognized",52 to implement the provisions of AP II. Article 1(1) of AP II expects "dissident armed forces or other organized armed groups which, under responsible command, exercise such control over a part of its territory as to enable them to

\footnotetext{
46 Article 96(3)(c), AP I.

47 Michael I. Handel, 'War termination: a critical survey', in Nissan Oren (ed), Termination of wars: processes, procedures and aftermaths (The Magnes Press 1982), at 23.

48 David Alonzo-Maizlish, 'When does it end? Problems in the law of occupation', in Roberta Arnold (ed), International humanitarian law and the 21st century's conflicts: changes and challenges (Editions universitaires suisses 2005), at 99 .

49 Eyal Benvenisti, The international law of occupation (Princeton University Press 1993), at 145 .

50 Article 6, GC IV.

51 See Article 43, AP I.

$5^{2}$ McCoubrey \& White, International law and armed conflict, at 200.
} 
carry out sustained and concerted military operations and to implement this Protocol". Consequently, the provisions of AP II are applicable within the territory controlled by the rebel armed forces. As for the armed forces of the High Contracting Party, AP II shall apply within the whole of the territory. Also common Article 3 to the 1949 Geneva Conventions is applicable in such internal armed conflicts and is "equally binding on all parties to the conflict, irrespective of their share of responsibility for the breakdown of social harmony and for starting the struggle", as seen by Bugnion. ${ }^{53}$ With regard to the 1899-1907 Hague Regulations, their application is, according to McCoubrey and White, "more questionable since it is not claimed that a full jus in bello regime would apply to such internal conflicts. Nonetheless many violations of 'Hague' law in such a context might well be argued to contravene general human rights and in some cases might even attract international attention." 54

Of course, these non-international armed conflicts can have international dimensions as well. AP II clearly forbids that anything in its provisions can be invoked as a pretext for "intervening, directly or indirectly, for any reason whatever, in the armed conflict or in the internal or external affairs of the High Contracting Party in the territory of which that conflict occurs". ${ }^{55}$ In this respect, territorial sovereignty and integrity as well as the national unity of the respective state cannot be challenged. The involvement of external powers in non-international armed conflicts was greatly feared by the decolonised territories after the Second World War. They once used the right of selfdetermination as advocated by the UN Charter as a new ground of jus ad bellum to get protection as legitimate belligerents, but it would seem that they now invoke limitations on the use of force which the same Charter provides in its Article 2(4). Regardless of the altruistic or egoistic intentions of humanitarian intervention in such territories, IHL in such situations has become the object of conflicting interests. Falk's description of this tension between sovereignty and communitarian arguments is still relevant in today's world where spheres of influence are likely to be divided by the most powerful on the international plane but whose cost is shifted towards the international community as a whole:

Internal wars present expanding nations and blocs with opportunities for strategic expansion that do not involve the high risks of reaching those

\footnotetext{
53 François Bugnion, 'Jus ad bellum, jus in bello and non-international armed conflicts', (2003) 6 Yearbook of International Humanitarian Law, 167, at 186.

54 McCoubrey \& White, International law and armed conflict, at 200.

55 Article 3(2), AP II.
} 
self-destructive levels of conflict that are likely to attend major armed attacks across international boundaries. This political characteristic places heavy pressure upon nonintervention norms that are designed to restrain partisan foreign participation in domestic strife. This pressure is accentuated by the moral commitments that are held currently by many important international actors. Can there be any relevance of international law to internal war in such a situation? ${ }^{56}$

Indeed, in its Tadic's appeals judgment, the Tribunal argued that a noninternational armed conflict becomes internationalised when one of the nonstate armed groups is acting on behalf of a third State. ${ }^{57}$ The latter however should exercise overall control over the former. ${ }^{58}$ The judgment continued that the intervention of a third State through its troops in an existing noninternational armed conflict also internationalised that armed conflictyet dependent on the circumstances such international armed conflict may coexist alongside the existing non-international armed conflict. ${ }^{59}$

\subsubsection{Temporal Jurisdiction}

As opposed to international(ised) armed conflicts—at least traditionally, the issuance of declarations of war during non-international armed conflicts is irrelevant. The asymmetrical so-called "structural power"60 disadvantage of rebel armed forces against armed forces of the state pushes the rebels to have recourse to surprise and unnotified attacks. In the case of non-international armed conflicts, IHL, according to the ICTY in the Tadić case, "applies from the initiation of such armed conflicts [...] until [...] a peaceful settlement is achieved". ${ }^{61}$ However, as Article 1(2) of AP II stipulates, "this Protocol shall not apply to situations of internal disturbances and tensions, such as riots, isolated and sporadic acts of violence and other acts of a similar nature, as not being armed conflicts". Also the ICTY in its Tadić trial judgment refined the thresh-

$5^{6}$ Richard Falk, 'Janus tormented: the international law of internal war', in James N. Rosenau (ed), International aspects of civil strife (Princeton University Press 1964), at 188-89.

57 Prosecutorv. Tadić, ICTY, Appeals Chamber, Judgment, 15 July 1999, Case No. IT-94-1-A, at www.icty.org, para. 84. (Last accessed on 15 February 2015)

$5^{8}$ Id., para. 120. See also Tom Gal, 'Unexplored outcomes of Tadić: applicability of the law of occupation to war by proxy', (2014) 12 Journal of International Criminal Justice, 1.

59 Id., para. 84.

6o Detter De Lupis, at 15 .

61 Prosecutor v. Tadić, ICTY, Appeals Chamber, Decision on the Defence Motion for Interlocutory Appeal on Jurisdiction, 2 October 1995, Case No. IT-94-1-AR72, at www.icty .org, para. 70. (Last accessed on 15 February 2015) 
old to establish the existence of non-international armed conflict, namely "the intensity of the conflict and the organization of the (non-state) parties to the conflict" for the purpose to distinguish such non-international armed conflict "from banditry, unorganized and short-lived insurrections, or terrorist activities".62

Still, the limited encouragement of the applicability of rules of international armed conflict towards the rebels, ${ }^{63}$ as stated by the ICTY in the same Tadić case, does not "imply a partial or complete acknowledgement of their government" ${ }^{\prime \prime 4}$ and thus upholds the essentially unequal relationship between the warring parties. At the end of non-international armed conflicts, according to Article 2(2) of AP II, "all the persons who have been deprived of their liberty or whose liberty has been restricted for reasons related to such conflict, as well as those deprived of their liberty or whose liberty is restricted after the conflict for the same reasons, shall enjoy the protection of Article 5 and 6 until the end of such deprivation or restriction of liberty". Article 25 of AP II, however, does not specify the end of the hostilities, and in particular with regard to detained individuals. It says that:

In case a High Contracting Party should denounce this Protocol, the denunciation shall only take effect six months after the receipt of the instrument of denunciation. If, however, on the expiry of six months, the denouncing Party is engaged in the situation referred to in Article 1, the denunciation shall not take effect before the end of the armed conflict. Persons who have been deprived of liberty, or whose liberty has been restricted, for reasons related to the conflict shall nevertheless continue to benefit from the provisions of this Protocol until their final release.

\subsection{The Principle of Distinction}

\subsubsection{On Status and Privileges}

The early industrial war campaigns in Europe and the industrial rate at which they were killing peoples soon became, according to Prins, "morally intolerable

62 Prosecutorv. Tadić, ICTY, Trial Chamber, Judgment, 7 May 1997, Case No. IT-94-1-T, at www .icty.org, para. 562. (Last accessed on 15 February 2015)

63 Theodor Meron, War crimes law comes of age: essays (Oxford University Press 1998), at 138 .

64 Article 152, 1863 Instructions for the Government of Armies of the United States in the Field, General Orders No. 100 (Lieber Code). 
and politically useless".65 During the First World War, IHL did not conceptualise a civilian population which could be distinguished from combatants as such and for those reasons it did not receive the protection it deserved if this had been the case. ${ }^{66}$ The technological developments of aerial warfare in particular enabled not only to destroy but also to inflict terror upon the civilians who were considered to be part of the enemy forces. Civilians were considered to be giving their support to the industrial warfare machine of the enemy. ${ }^{67}$ Such perception of civilian involvement dominated the discourse of warfare for a long time. This alleged behaviour of the civilian population would, in the eyes of the soldiers, become the benchmark against which they had to assess their actions. Later, however, this approach on such alleged behaviour turned its focus on the status of the individual instead. Although, in this shift, "civilians clearly have not done anything to warrant attacks or to warrant immunity from attacks", ${ }^{68}$ as understood by May, the principle of distinction would seem to be constructed upon those moral and conceptual grounds. Hence, the inherent vulnerability and the status of the civilian population would transcend the accusations of their alleged behaviour and actions. ${ }^{69}$

In this respect, IHL's ambitions to advance the standard of civilisation by granting non-combatant immunity, i.e. immunity from attack, to civilians and those no longer participating in armed hostilities, i.e. hors de combat, do not necessarily reflect the moral, military and political necessities in armed conflict. This latter argument based on necessity might justify any means to be used to win the war and to defend one's survival. For example, as Best continues, "war's new weapons of mass destruction and means of delivering them made it horribly easy to maximize non-combatant non-protection". ${ }^{70}$ Nonetheless, in its Nuclear Weapons advisory opinion, the International Court of Justice (ICJ) endorsed the principle of distinction and its corresponding prohibition to attack civilians and to inflict unnecessary suffering upon combatants. ${ }^{71}$ The

65 Gwyn Prins, 'Civil and uncivil wars', in Gwyn Prins \& Hylke Tromp (eds), The future of war (Kluwer Law International 2000), at 215.

66 Amanda Alexander, 'The genesis of the civilian', (2007) 20 Leiden Journal of International Law, 359, at 365 .

67 Id., at 369 .

68 Larry May, War crimes and just war (Cambridge University Press 2007), at 175.

69 Id., at 187.

70 Best, at 26o. (Emphasis added by Best)

71 Jan Wouters \& Frederik Naert, 'Shockwaves through international law after 11 September: finding the right responses to the challenges of international terrorism', in Cyrille Fijnaut, Jan Wouters \& Frederik Naert (eds), Legal instruments in the fight against international terrorism: a transatlantic dialogue (Martinus Nijhoff Publishers 2004), at 478. 
Court stated that these "cardinal principles [...] constitute intransgressible principles of international customary law".72 However, the idealist endeavour to protect civilians during warfare would still need to be balanced against the realist nature of war which makes full protection impossible. ${ }^{73}$

The disproportionate number of civilian casualties during the Second World War as compared to military ones in previous wars ${ }^{74}$ would call for a restriction on the use of so-called "inherently indiscriminate" 75 weapons. Prior to the application of the protections granted by the principle of discrimination, ${ }^{76}$ the determination of the civilian or military purpose of the object of target would need to be addressed first. ${ }^{77}$ The customary IHL study of the ICRC states that "military objectives are limited to those objects which by their nature, location, purpose or use make an effective contribution to military action and whose partial or total destruction, capture or neutralisation, in the circumstances ruling at the time, offers a definite military advantage". ${ }^{78}$ This definition clearly upholds that the only "legitimate object"79 of warfare is the weakening of the opponent's armed forces. Consequently, no positive definition of civilian objects would be necessary as they would be the negation of the only legitimate objects of attack, i.e. the military objectives. ${ }^{80}$ This theoretical distinction is particularly important on the battlefield. According to Kalshoven, "the abstract concept of general protection of the civilian population against the dangers of hostilities can be clarified somewhat by distinguishing two situations. One is that of the attack on the civilian population, or on members of the civilian population, as such. The other situation is that of the attack on

72 Legality of the Threat or Use of Nuclear Weapons in Armed Conflict, ICJ, Advisory Opinion, 8 July 1996, I.C.J. Reports 1996, at http://www.icj-cij.org/docket/files/95/7495.pdf, paras. 78-9. (Last accessed on 15 February 2015)

73 Best, at 325 .

74 Robert J. Mathews \& Timothy L.H. McCormack, 'The relationship between international humanitarian law and arms control', in Helen Durham \& Timothy L.H. McCormack (eds), The changing face of conflict and the efficacy of international humanitarian law (Martinus Nijhoff Publishers 1999), at 72.

Id., in, at 73 .

76 Kenneth Watkin, '21st century conflict and international humanitarian law: status quo or change?' in Michael N. Schmitt \& Jelena Pejic (eds), International law and armed conflict: exploring the faultlines: essays in honour of Yoram Dinstein (Martinus Nijhoff Publishers 2007), at 284 .

77 Detter De Lupis, at 233 and 239.

78 Henckaerts \& Doswald-Beck, at 29. See also Article 52(2), AP I.

791868 Declaration of St. Petersburg.

8o Henckaerts \& Doswald-Beck, at 32. 
a military objective which affects the civilian population." ${ }^{81}$ Therefore, civilian categorisations are ambiguous for the belligerent parties whose enmity towards each other trumps the harmlessness of civilian identities. ${ }^{82}$

Similar difficulties have risen when characterising the status of noncombatants and combatants. The non-combatants include all "persons who are not members of the armed forces"83 and those combatants hors de combat, i.e. no longer taking part in armed hostilities. ${ }^{84}$ Although the vulnerable position of civilians was unquestionable in doctrine, in practice the definition of combatancy turned the civilian's status back to its alleged behaviour. According to customary IHL, civilians are immune from attack "unless and for such time as they take a direct part in hostilities". 85 The ICRC "Interpretive Guidance on the Notion of Direct Participation in Hostilities under International Humanitarian Law" corroborates this customary rule: "For the purposes of the principle of distinction in international armed conflict, all persons who are neither members of the armed forces of a party to the conflict nor participants in a levée en masse are civilians and, therefore, entitled to protection against direct attack unless and for such time as they take a direct part in hostilities." ${ }^{\text { } 6}$ In any given circumstance, it is impossible to dissociate the protective status from the actual conduct. Or as Dinstein puts it, "a person is not allowed to wear simultaneously two caps: the hat of a civilian and the helmet of a soldier". ${ }^{87} \mathrm{IHL}$ does not accommodate part-time or unlawful combatancy ${ }^{88}$ which in practice

81 Frits Kalshoven, The law of warfare: a summary of its recent history and trends in development (Henry Dunant Institute 1973), at 60.

82 Hugo Slim, Killing civilians: method, madness and morality in war (Hurst \& Co. 2007), at 184 .

83 Henckaerts \& Doswald-Beck, at 17.

84 Detter De Lupis, at 243; For further discussion on direct participation in armed hostilities, see Michael N. Schmitt, 'The interpretive guidance on the notion of direct participation in hostilities: a critical analysis', (2010) 1 Harvard National Security Journal, 5; Michael N. Schmitt, 'Deconstructing direct participation in hostilities: the constitutive elements', (2009-2010) 42 New York University Journal of International Law and Politics, 697; Kenneth Watkin, 'Opportunity lost: organized armed groups and the ICRC "Direct Participation in Hostilities" interpretive guidance', (2009-2010) 42 New York University Journal of International Law and Politics, 641.

85 Henckaerts \& Doswald-Beck, at 19.

86 ICRC, Interpretive Guidance on the Notion of Direct Participation in Hostilities under International Humanitarian Law (ICRC 2009), at 16.

87 Yoram Dinstein, The conduct of hostilities under the law of international armed conflict (Cambridge University Press 2004), at 29.

88 Jelena Pejic, “'Unlawful/Enemy combatants”: interpretations and consequences', in Michael N. Schmitt \& Jelena Pejic (eds), International law and armed conflict: exploring 
has often taken place. Such so-called "strategic instrumentalization"89 of those legal categories in practice undermines the clearly defined nature of such stable legal categories. Therefore, IHL as it stands, treats protected civilians who commit "belligerent acts" 90 as unprivileged and they loose their non-combatant immunity; while the privileged combatants can be prosecuted for certain acts beyond their belligerency when violating IHL.

Upon capture and imprisonment of those unlawful combatants, the United States Supreme Court before its 1942 Quirin case argued that these "are subject to trial and punishment by military tribunals for acts which render their belligerency unlawful". ${ }^{91}$ Hence, such treatment denies the favourable prisoner of war's entitlements ${ }^{92}$ and, as Baxter argues, "neglects to protect unprivileged belligerents because of the danger their acts present to their opponents". ${ }^{93}$ Against this background, Maxwell and Watts conclude that "only by removing the fighter entirely from the classification system of the existing positive law of war can one reasonably posit that he is not entitled to the fundamental due process guarantees of the law of war and simultaneously is criminally liable merely on the basis of his extra-conventional status". ${ }^{94}$ The latter situation has been rejected by the United States Supreme Court in its Hamdan v. Rumsfeld ruling as such narrow interpretation would breach the 1949 Geneva Conventions. ${ }^{95}$ Though, such military practices have until today further destabilised IHL at the so-called "level of participant identity"; $; 6$ these same military practices have again confirmed the close interaction between the legal

the faultlines: essays in honour of Yoram Dinstein (Martinus Nijhoff Publishers 2007), at 338 .

89 Nathaniel Berman, 'Privileging combat? Contemporary conflict and the legal construction of war', (2004-2005) 43 Columbia Journal of Transnational Law, 1, at 54.

90 Charles H.B. Garraway, '"Combatants": substance or semantics?' in Michael N. Schmitt \& Jelena Pejic (eds), International law and armed conflict: exploring the faultlines: essays in honour of Yoram Dinstein (Martinus Nijhoff Publishers 2007), at 331.

91 Ex parte Quirin et al., US Supreme Court, Judgment, 31 July 1942, 317 US [Supreme Court Reports] 1 (1942), at 30-1.

92 Knut Dörmann, 'The legal situation of "unlawful/unprivileged combatants"', (2003) 85 International Review of the Red Cross, 45, at 46.

93 Richard R. Baxter, 'So-called "unprivileged belligerency": spies, guerrillas, and saboteurs', (1951) 28 British Yearbook of International Law, 321, at 328.

94 Mark David Maxwell \& Sean M. Watts, “Unlawful enemy combatant”: status, theory of culpability, or neither?', (2007) 5 Journal of International Criminal Justice, 19, at 23-4.

95 Michael C. Dorf, 'The Orwellian Military Commissions Act of 2006', (2007) 5 Journal of International Criminal Justice, 10, at 18.

96 Berman, at 51 . 
standing of their adversaries to use force, i.e. jus ad bellum, and their legitimate belligerency, i.e. jus in bello. ${ }^{97}$

\subsubsection{International Armed Conflicts}

Despite the customary nature of the principle of distinction, ${ }^{98}$ it was for the first time in history that this principle and its related immunity for noncombatants have been explicitly codified by a legal instrument, namely by AP I, in its Article 48:99 "In order to ensure respect for and protection of the civilian population and civilian objects, the Parties to the conflict shall at all times distinguish between the civilian population and combatants and between civilian objects and military objectives and accordingly shall direct their operations only against military objectives." ${ }^{100}$ In addition, Article 3(2) of the 1980 Protocol on Prohibitions or Restrictions on the Use of Mines, BoobyTraps and Other Devices (Protocol II), Article 3(7) of its 1996 amended version and Article 2(1) of the 1980 Protocol on Prohibitions or Restrictions on the Use of Incendiary Weapons (Protocol III) have also legalised this distinction. Nevertheless, as Article 52(3) of AP I establishes, "in case of doubt whether an object is normally dedicated to civilian purposes [...] is being used to make an effective contribution to military action, it shall be presumed not to be so used". Apparently, this Article 52(3) of AP I relativises the definition of military objectives. ${ }^{101}$ Even a later precision of military objectives in Article 52(2) of AP I remains as abstract and non-specific. ${ }^{102}$ Still, Articles 51(4)-(5) of AP I further elaborate on indiscriminate attacks. According to Article 54(2) of AP I,

it is prohibited to attack, destroy, remove or render useless objects indispensable to the survival of the civilian population, such as foodstuffs, agricultural areas for the production of foodstuffs, crops, livestock, drinking water installations and supplies and irrigation works, for the specific purpose of denying them for their sustenance value to the civilian population or to the adverse Party, whatever the motive, whether in order to starve out civilians, to cause them to move away, or for any other motive.

\footnotetext{
97 Id., at $56-7$.

98 Peter Rowe, Defence: the legal implications: military law and the laws of war (Brassey's Defence Publishers 1987), at 148.

99 Judith Gail Gardam, Non-combatant immunity as a norm of international humanitarian law (Martinus Nijhoff Publishers 1993), at 109.

100 Article 48, AP I.

101 Best, at 272.

102 Dinstein, at 83.
} 
Also attacks on "works or installations containing dangerous forces"103 are prohibited given the risk of release of dangerous forces would indiscriminately affect the civilian population. Linked with this, according to Article 55 of AP I, is the protection of the natural environment from those attacks which cause "widespread, long-term and severe damage" and thereby "prejudice the health or survival or the population". This so-called "interrelationship of man and nature"104 and the protection of nature ${ }^{105}$ was already validated by the 1976 Convention on the Prohibition of Military or any Hostile Use of Environmental Modification Techniques; whereas Article 35(3) of AP I exclusively deals with the environment. ${ }^{106}$ The 1923 Hague Rules of Air Warfare which give a more illustrative exposition of allowed and prohibited targets as well as the 1954 Convention for the Protection of Cultural Property in the Event of Armed Conflict (as referred to by Article 53 of AP I) can also be seen in this light. In addition, no military objectives, according to Article 51(7) of AP I can be shielded with civilians and thus similarly reaffirms Article 28 of GC IV which prohibits their presence "to render certain points or areas immune from military operations". The same prohibition also applies for prisoners of war. ${ }^{107}$

With regard to individuals licensed to kill and their privilege to commit legitimate belligerent acts, Article 51(3) of AP I corroborates the customary rule on the exception to non-combatant immunity in case of direct participation in armed hostilities. ${ }^{108}$ Non-combatants simply cannot legally take part in combat. ${ }^{109}$ In case of ambiguity, there exists, according to Article 5o(3) of AP I, a presumption that everybody "who does not come with the definition of civilians" remains under the protective status of the civilian (population) upon the condition of course that no belligerent acts have been committed. In international armed conflicts, the protection of captured civilians would be complementary to the one of prisoners of war as this protection would rely on that

103 Article 56, AP I.

104 Preamble, 1976 Convention on the Prohibition of Military or any Hostile Use of Environmental Modification Techniques.

105 Karen Hulme, War torn environment: interpreting the legal threshold (Martinus Nijhoff Publishers 2004), at 21.

106 McCoubrey, International humanitarian law: modern developments in the limitation of warfare, at 229 .

107 Article 23, GC III.

108 Pejic, in, at 337.

109 Margaret D. Stock, 'Detainees in the hands of America: new rules for a new kind of war', in Michael N. Schmitt \& Gian Luca Beruto (eds), Terrorism and international law: challenges and responses (International Institute of Humanitarian Law 2003), at 120. 
negative definition. ${ }^{110}$ Again, the status of protection has become dependent upon the perspective of the combatant, as enshrined in Article 4 of GC III; the civilian would be its negation. However, GC III does not refer to combatants when defining prisoners of war. ${ }^{111}$ Moreover, according to Naqvi, "it is submitted that the underlying principle establishing a general presumption of prisoner-of-war status for those participating in hostilities is developing into a customary rule". ${ }^{12}$ Until such time, human treatment has to be guaranteed. ${ }^{113}$

In its Delalić and Delić judgment, ${ }^{114}$ the ICTY stated that any individual apprehended by the adversary armed forces shall benefit from the protective status of the civilian under GC IV or of the prisoner of war under GC III. ${ }^{115}$ Nonetheless, unlawful combatancy enters again into the picture whenever such protection needs to be guaranteed by the High Contracting Parties. Although, according to Article 5 of GC III, combatants who have acted beyond their belligerency and whose belonging to any of the categories entitled to prisoner of war as outlined in Article 4 of GC III is doubtful, they shall continue to enjoy the protection of prisoner of war "until such time as their status has been determined by a competent tribunal". Or in more general terms, any "person who takes part in hostilities and falls into the power an adverse Party shall be presumed to be a prisoner of war".116 On the contrary, all perfidious actions would be indicative of the lack of central command on those members of such armed forces. These violators, in case of capture, do not deserve the full privileges which AP I and GC III provide. ${ }^{117}$ In addition, mercenaries, according to Article 47 of AP I, "shall not have the right to be a combatant or a

110 José Luis Rodríguez-Villasante y Prieto, 'Terrorist acts, armed conflicts and international humanitarian law', in P.A. Fernández-Sánchez (ed), The new challenges of humanitarian law in armed conflicts: in honour of professor Juan Antonio Carrillo-Salcedo (Martinus Nijhoff Publishers 2005), at 33.

111 Detter De Lupis, at 117.

112 Yasmin Naqvi, 'Doubtful prisoner-of-war status', (2002) 84 International Review of the Red Cross, 571, at 592.

113 Horst Fischer, 'Protection of prisoners of war', in Dieter Fleck (ed), The handbook of international humanitarian law (Oxford University Press 2008), at 378.

114 Prosecutor v. Delalić and Delić, ICTY, Trial Chamber, Judgment, 16 November 1998, Case No. IT-96-21-T, at www.icty.org, para. 271. (Last accessed on 15 February 2015)

115 Luigi Condorelli \& Yasmin Naqvi, "The war against terrorism and jus in bello: are the Geneva Conventions out of date?' in Andrea Bianchi \& Yasmin Naqvi (eds), Enforcing international law norms against terrorism (Hart Publishing 2004), at 35 .

116 Article 45(1), AP I.

117 Henckaerts \& Doswald-Beck, at 384; in particular Article 44(4), AP I. 
prisoner of war"; the 1989 International Convention against the Recruitment, Use, Financing and Training of Mercenaries further deals with this matter.

Clearly, the legitimacy of combatancy has particularly been favourable for professional armies and the levée en masse, ${ }^{118}$ i.e. the "inhabitants of a nonoccupied territory, who on the approach of the enemy spontaneously take up arms to resist the invading forces, without having had time to form themselves into regular armed units, provided they carry arms openly and respect the laws and customs of war". 119 While there is no obligation under IHL to wear uniforms, ${ }^{120}$ wearing civilian clothing is only illegal when killing and wounding treacherously those individuals who belong "to the hostile nation or army".121 However, outside the actions of the levée en masse, Article 44(3) of AP I, considers the lack of other visible criteria to be perfidious, except for the carrying of arms openly. Particularly, in the context of occupation and decolonisation without real military fronts, ${ }^{122}$ the immunity of such conduct of those combatants or their legitimate belligerency under the jus in bello would recognise the legitimacy of their insurgency or cause under the jus ad bellum against the occupying or colonial armies. ${ }^{123}$ The lack of true distinction by a potentially growing army of irregular armed forces might produce even more civilian casualties.

\subsubsection{Non-International Armed Conflicts}

Although common Article 3 to the 1949 Geneva Conventions provides a minimum standard of protection to civilians and combatants hors de combat, it does not explicitly reveal the principle of distinction. This principle could be inferred from the prohibited acts mentioned in the same Article 3(1)(a), i.e. "violence to life and person". Similarly, the same fundamental standards of humane treatment have been reproduced within Article 4(2) of AP II, i.e. "violence to the life [...] of persons". Consequently, AP II did not truly remedy this gap of protection; its Article 13 would only be a restatement of Article 51 of AP I's first paragraphs. Moreover, the non-combatant immunity as codified

118 Karma Nabulsi, Traditions of war: occupation, resistance, and the law (Oxford University Press 2005), at 16-7; see also Articles 49 and 51, Lieber Code and Article 2, Annex 1907 Hague IV.

119 Article 4(A)(6), GC III.

120 Toni Pfanner, 'Military uniforms and the law of war', (2004) 86 International Review of the Red Cross, 93, at 104.

121 Article 23(b), Annex to 1907 Hague IV.

122 Michel Veuthey, Guérilla et droit humanitaire (Institut Henry-Dunant 1983), at 21.

123 Berman, at 56. 
by Article 48 of AP I does not have its equivalent international recognition in non-international armed conflicts. ${ }^{124}$ However, according to Kalshoven, ${ }^{125} \mathrm{a}$ limited recognition of this privilege can be deduced from Article 7 of AP II: "All the wounded, sick and shipwrecked, whether or not they have taken part in the armed conflict, shall be respected and protected."

Nonetheless, as reaffirms the customary IHL study by the ICRC, "the lawfulness of direct participation in hostilities in non-international armed conflicts is governed by national law".126 Article 1(1) of AP II, on the international legal dimension, only specifies that "dissident armed forces of other organized armed groups" should be "under responsible command". Hence, civilians are again defined negatively as opposed to the membership to one of these groups. Their protection, however, according to Article 13(3) of AP II finishes "for such a time they take a direct part in hostilities". According to Berman, "common Article 3 and Protocol II are thus consistent with the statist and governmentalist biases that inform the legal construction of war". ${ }^{127}$ Such fewer criteria of combatant status' can lead to more indiscriminate attacks ${ }^{128}$ and a lesser "sense of duty towards international obligations agreed to by the very government to which [the rebels] are so violently opposed", as Moir continues. ${ }^{129}$ In addition, the customary IHL protection of the principle of humanity and the dictates of public conscience as referred to in Article 1(2) of AP I for international armed conflicts have no legally binding equivalent for internal armed conflicts despite its reference in the Preamble of AP II. ${ }^{130}$

\footnotetext{
124 Gardam, at 128.

125 Frits Kalshoven, 'Reaffirmation and development of international humanitarian law applicable in armed conflicts: the Diplomatic Conference, Geneva, 1974-1977, Part I: combatants and civilians', (1977) 8 Netherlands Yearbook of International Law, 106, at 118-19.

126 Henckaerts \& Doswald-Beck, at 13.

127 Berman, at 20.

128 Detter De Lupis, at 117 .

129 Lindsay Moir, The law of internal armed conflict (Cambridge University Press 2002), at 53; see also

130 Michael Bothe, Karl Josef Partsch \& Waldemar A. Solf, New rules for victims of armed conflicts: commentary on the two 1977 protocols additional to the Geneva Conventions of 1949 (Martinus Nijhoff Publishers 1982), at 620.
} 


\subsection{The Principle of Proportionality}

\subsubsection{On Humanity and Necessity}

Whenever the principle of distinction and its corollary non-combatant immunity have been considered by the armed forces for their military actions, the principle of proportionality shall continue to direct their conduct. It is a customary rule of IHL that "launching an attack which may be expected to cause incidental loss of civilian life, injury to civilians, damage to civilian objects, or a combination thereof, which would be excessive in relation to the concrete and direct military advantage anticipated, is prohibited".131 Also strategic motivations to take advantage of the substantial value of the civilian resources guided the conquering armies during and after the war. ${ }^{132}$ Consequently, as so-called "ethical baselines", ${ }^{133}$ proportionality and the protection of civilians through humane treatment are inseparable. ${ }^{134}$ Besides, the positive obligation of humane treatment and the negative one of proportionality and necessity would cancel each other out. Moreover, as Kennedy continues, the "injuries of wartime are also permissible, privileged, structured by law".135

Despite the aim to fully comply with protective norms, collateral damage remains difficult to avoid. ${ }^{136}$ Though, from an utilitarian perspective, ${ }^{137}$ the means of warfare would have to rationally bring about the anticipated military purpose with the least possible injurious harm. ${ }^{138}$ However, the principle of necessity seems to destroy, as May argues, "the possibility of there being any absolute, or near absolute, prohibitions during war, because a war may be

131 Henckaerts \& Doswald-Beck, at 46. See also Article 51(5)(b), Article 57(2)(a)(iii) \& Article $57(2)(\mathrm{b})$, AP I.

132 Geoffrey Francis Andrew Best, 'Restraints on war by land before 1945', in Michael Howard (ed), Restraints on war (Clarendon Press 1977), at 20-8.

133 David Kennedy, 'Reassessing international humanitarianism', in Anne Orford (ed), International law and its others (Cambridge University Press 2006), at 138.

134 Edward K. Kwakwa, The international law of armed conflict: personal and material fields of application (Kluwer Academic Publishers 1992), at 39.

135 David Kennedy, Of war and law (Princeton University Press 2006), at 114.

${ }_{13} 6$ Jean Pictet, Development and principles of international humanitarian law: course given in July 1982 at the University of Strasbourg as part of the courses organized by the International Institute of Human Rights (Martinus Nijhoff Publishers 1985), at 88.

137 May, at 211.

${ }_{13} 8$ Amichai Cohen \& Yuval Shany, 'A development of modest proportions: the application of the principle of proportionality in the Targeted Killings case', (2007) 5 Journal of International Criminal Justice, 310, at 312. 
merely a series of military necessities". ${ }^{139}$ Again, such entitlement legitimises to violate both jus ad bellum and jus in bello. The principles of proportionality and humanity would only be functional to limit the instrumental necessities of war. In addition, customary IHL states that "all feasible precautions must be taken to avoid, and in any event to minimise, incidental loss of civilian life, injury to civilians and damage to civilian objects". ${ }^{140}$ Hence, as restatements of the principle of necessity, ${ }^{141}$ the precaution by which necessity operates would, as Duffy puts it, "ensure the lawfulness of a military attack". ${ }^{142}$ In this way, possible future reconciliation ${ }^{143}$ between the warring parties might be guaranteed and might offer "a better peace", as seen by Howard. ${ }^{144}$ The cornerstone of humanity in the jus in bello is inextricably linked with accountability under the jus post bellum.

More concretely, whenever the object of targeting has been determined, proportionality shall prohibit particular weaponry causing "superfluous injury and unnecessary suffering"145 and shall affect the way weaponry is being used in particular circumstances. ${ }^{146}$ Thus, as another customary rule of IHL stipulates, "each party to the conflict must take all feasible precautions in the choice of means and methods of warfare with a view to avoiding, and in any event to minimise, incidental loss of civilian life, injury to civilians and damage to civilian objects". ${ }^{147}$ But, so-called technologically "advanced military powers"148 actually possess such banned and other indiscriminate weapons. Best argues that the "risk of horrors accompanying [their] use"149 would remain "a matter of regret". ${ }^{150}$ In this respect, arms control treaties in general could provide

\footnotetext{
139 May, at 197.

140 Henckaerts \& Doswald-Beck, at 51.

141 Kwakwa, at 37.

142 Helen Duffy, The "war on terror" and the framework of international law (Cambridge University Press 2005), at 235 .

143 Michael Howard, 'Temperamenta belli: can war be controlled?' in Michael Howard (ed), Restraints on war: studies in the limitation of armed conflict (Oxford University Press 1979), at 14 .

144 Id., in, at 14.

145 Mathews \& McCormack, in, at 71.

146 Detter De Lupis, at 136.

147 Henckaerts \& Doswald-Beck, at 56.

148 Best, War and law since 1945, at 324 .

149 Id., at 306.

150 Id., at 306.
} 
less industrially advanced parties to escape an arms race ${ }^{151}$ of such inhumane weaponry. At the same time, such treaties could also "increase mistrust and spiralling expenditures", as seen by Keefer. ${ }^{152}$ Moreover, it is most likely that the technological inferior parties would have recourse to less conventional and indiscriminate methods and means of warfare ${ }^{153}$ in order to ultimately compete for the support of the civilian population..$^{154}$

Evidently, the issue of precision-guided weaponry is de facto linked with the requirements of proportionality it wants to safeguard. Schmitt, however, argues that "the extent of harm and damage is relevant only in relation to the military advantage reasonably expected as the attack was launched". 155 In this respect, indiscriminate attacks with civilian casualties as a result are necessarily condemned of being reckless. Consequently, another spiral of indiscriminate warfare will spur out of this asymmetrical violence. Nonetheless, in spite of the rapid technological evolution in military affairs, ${ }^{156}$ the Martens clause is part of customary IHL. ${ }^{157}$ But, according to the 1868 Declaration of St. Petersburg, "the Contracting or Acceding Parties reserve to themselves to come hereafter to an understanding whenever a precise proposition shall be drawn up in view of future improvements which science may effect in the armament of troops, in

151 Scott Andrew Keefer, 'Building the palace of peace: The Hague Conference of 1899 and arms control in the progressive era', (2006) 8 Journal of the History of International Law, 1 , at 8 .

$15^{2}$ Id., at 65 .

153 Michael N. Schmitt, "The impact of high and low-tech warfare on the principle of distinction', in Roberta Arnold (ed), International humanitarian law and the 21st century's conflicts: changes and challenges (Editions universitaires suisses 2005), at 177; See also Gabriella Blum, 'On a differential law of war', (2011) 52 Harvard International Law Journal, 163.

154 Karine Bannelier, 'L'influence de la guerre asymétrique sur les règles du jus in bello', in Karine Bannelier (ed), L'intervention en Irak et le droit international (Pedone 2004), at 148 .

155 Michael N. Schmitt, 'Precision attack and international humanitarian law', (2005) 87 International Review of the Red Cross, 445, at 457.

156 Legality of the Threat or Use of Nuclear Weapons in Armed Conflict, ICJ, Advisory Opinion, 8 July 1996, I.C.J. Reports 1996, at http://www.icj-cij.org/docket/files/95/7495.pdf, para. 78. (Last accessed on 15 February 2015)

157 Robin M. Coupland, 'The SIrUS Project: towards a determination of which weapons cause "superfluous injury or unnecessary suffering", in Helen Durham \& Timothy L.H. McCormack (eds), The changing face of conflict and the efficacy of international humanitarian law (Martinus Nijhoff Publishers 1999), at 103; see also a discussion by Antonio Cassese, 'The Martens clause: half a loaf or simply pie in the sky?', (2000) 11 European Journal of International Law, 187. 
order to maintain the principles which they have established, and to conciliate the necessities of war with the laws of humanity."158 However, the determination of necessity remains at the discretion of the military commander. ${ }^{159}$

\subsubsection{International Armed Conflicts}

During international armed conflicts, proportionality shall also govern the treatment of the adversaries' combatants and civilian population in order to minimise their suffering. With regard to the situation of non-combatants, "each High Contracting Party shall allow the free passage of all consignments of medical and hospital stores, [...] of essential foodstuffs, clothing and tonics intended for children under fifteen, expectant mothers and maternity cases". 160 As a corollary to the customary prohibition of "starvation of civilians as a method of warfare" confirmed by Article 54(1) of AP I, the protection of such collective relief schemes has to be guaranteed by the High Contracting Parties. ${ }^{161}$ Article 23 and 59 of GC IV, however, continue that the free passage of those goods enabling the humane treatment and survival of those vulnerable groups is subjected to the fear that they "may accrue to the military efforts or economy of the enemy". ${ }^{162}$ The latter contrasts with the general observations of Article 27 of GC IV which states that all protected persons "shall at all times be humanely treated". Moreover, denying such humanitarian goods in particular would circumvent the minimum humane treatment as spelled out in Article 75 of AP I, inspired by common Article 3 to the 1949 Geneva Conventions and obey the more general prohibition of Article 32 of GC IV where:

The High Contracting Parties specifically agree that each of them is prohibited from taking any measure of such a character as to cause the physical suffering or extermination of protected persons in their hands. This prohibition applies not only to murder, torture, corporal punishment, mutilation and medical or scientific experiments not necessitated by the medical treatment of a protected person, but also to any other measures of brutality whether applied by civilian or military agents.

\footnotetext{
1581868 Declaration of St. Petersburg.

159 Mika Nishimura Hayashi, 'The Martens clause and military necessity', in Howard M. Hensel (ed), The legitimate use of military force: the just war tradition and the customary law of armed conflict (Ashgate 2009), at 139-40.

16o Article 23, GC IV.

161 Article 59, GC IV and Article 70(4) AP I.

162 Article 23(c), GC IV.
} 
Such provisions are closely associated with the principle of distinction which in this particular context refer to the prohibition of collective punishment against civilians ${ }^{163}$ and individuals hors de combat ${ }^{164}$ as a disproportionate measure which sets aside the individual responsibility of the members of the civilian populations for their wrong-doing. With regard to the prisoners of war, humane treatment and protection are mandatory "at all times [...] against acts of violence or $[\ldots]$ physical mutilation or $[\ldots]$ medical or scientific experiments of any kind which are not justified by the medical, dental or hospital treatment of the prisoner concerned and carried out in his interest". ${ }^{165}$ Also alimentary, clothing, medical, sanitary and shelter obligations are imposed upon the Detaining Power. ${ }^{166}$

Not only general treaties ${ }^{167}$ on the conduct of hostilities during international armed conflicts prohibit the use of such "means and methods of warfare which are of a nature to cause superfluous injury or unnecessary suffering", ${ }^{168}$ also certain weapons conventions ${ }^{169}$ reflect this customary rule of IHL. However, the protocols on incendiary and blinding laser weapons ${ }^{170}$ do not prohibit

163 Article 50, Annex 1907 Hague IV; Article 33, para. 1, GC IV; Article 75(2)(d), AP I.

164 Article 87, para. 3, GC III.

165 Article 13, GC III.

166 See Articles 20-32, GC III; Articles 10-11, AP I.

1671868 Declaration of St. Petersburg; 1899 Hague IV, 2; 1899 Hague IV, 3; Article 23(e), Annex 1899 Hague II, Article 23(e); Annex 1907 Hague IV; Article 35(2), AP I.

168 Henckaerts \& Doswald-Beck, at 237. See also Article 35(3), AP I.

169 Preamble, 1980 Convention on Prohibitions or Restrictions on the Use of Certain Conventional Weapons Which May be Deemed to be Excessively Injurious or to Have Indiscriminate Effects; 1980 Protocol on Non-Detectable Fragments (Protocol I); Article 6(2), 1980 Protocol on Prohibitions or Restrictions on the Use of Mines, Booby-Traps and Other Devices (Protocol II); Article 3(3), 1996 Amended Protocol on Prohibitions or Restrictions on the Use of Mines, Booby-Traps and Other Devices; Preamble, 1997 Convention on the Prohibition of the Use, Stockpiling, Production and Transfer of AntiPersonnel Mines and on their Destruction. The 1925 Protocol for the Prohibition of the Use of Asphyxiating, Poisonous or Other Gases, and of Bacteriological Methods of Warfare is inspired by the same prohibition already present within Article 7o, Lieber Code and Article 23(e), Annex 1899 Hague II and 1907 Hague IV. It has been reproduced by later conventions such as the 1972 Convention on the Prohibition of the Development, Production and Stockpiling of Bacteriological (Biological) and Toxin Weapons and on their Destruction and the 1993 Convention on the Prohibition of the Development, Production, Stockpiling and Use of Chemical Weapons and on their Destruction.

170 Articles 1(5) and 2(3), 1980 Protocol on Prohibitions or Restrictions on the Use of Incendiary Weapons (Protocol III); Article 2, 1995 Protocol on Blinding Laser Weapons (Protocol IV). 
their use but insist instead on the so-called "precautionary measures"171 to be taken when employing them; and this to avoid a violation of the princicple of proportionality in the conduct of armed hostilities. In this regard, according to Article 51(5)(b) of AP I, indiscriminate attacks "which may be expected to cause incidental loss of civilian life, injury to civilians, damage to civilian objects, or combination thereof, which would be excessive in relation to the concrete and direct military advantage anticipated". Besides the "constant

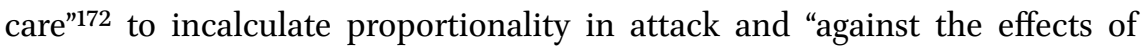

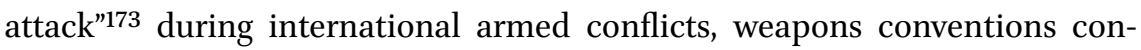
tinue to play an important role in the aftermath of warfare. Because, also the remnants of war cause, according to the 2003 Protocol on Explosive Remnants of War, "serious post-conflict humanitarian problems". ${ }^{174}$ Moreover, these remnants of war have "severe consequences"175 to the security of civilian population. Therefore, on the level of the reconciliation process, any disproportionate military action like the ones mentioned above shall affect the accountability for those violations. ${ }^{176}$

\subsubsection{Non-International Armed Conflicts}

Common Article 3 to the 1949 Geneva Conventions and Part II of AP II explicitly deal with the humane treatment at all times of "all persons who do not take a direct part or who have ceased to take part in hostilities". 177 The protection of the civilian population against starvation and the prohibition of all means and methods of war having this direct or indirect influence upon the former are regulated both by customary and treaty law. In spite of this prohibition enacted by Article 14 AP II, no provisions safeguard the actual "access of humanitarian relief even though such access is clearly a conditio sine qua non for relief actions". ${ }^{178}$ However, the "freedom of movement of authorised humanitarian relief personnel",179 as a customary rule of IHL, remains "subject

\footnotetext{
171 Article 51(8), AP I.

172 Article 57 (1), AP I.

173 Article 58, AP I; see also Article 3(10), 1996 Amended Protocol on Prohibitions or Restrictions on the Use of Mines, Booby-Traps and Other Devices.

174 Preamble, 2003 Protocol on Explosive Remnants of War (Protocol V).

175 Preamble, 2008 Convention on Cluster Munitions; Preamble, 1997 Convention on the Prohibition of the Use, Stockpiling, Production and Transfer of Anti-Personnel Mines and on their Destruction.

176 Article 5o, GC I; Article 51, GC II; Article 130, GC III; Article 147, GC IV; Article 85, AP I.

177 Article 4(1), AP II.

178 Henckaerts \& Doswald-Beck, at 194-95.

179 Id., at 200.
} 
to the consent of the High Contracting Party" as stipulated by Article 18(2) of AP II. Consequently, military necessity can still be invoked by the warring parties in order to curtail such obligation under customary IHL. Although state practice gives sufficient support to a customary rule in those situations, the limited legal certainties which IHL gives to those helpless individuals can, as during international armed conflicts, be supplemented by human rights law applicable during peacetime and wartime.

Regarding the conduct of hostilities, no explicit reference has been made in AP II to the principle of proportionality nor to the precautionary measures during and against the effects of attack. Nowadays, given the customary nature of their obligation, they are, however, applicable in non-international armed conflicts. Also the customary prohibition on "the use of means and methods of warfare which are of a nature to cause superfluous injury or unnecessary suffering"180 applies in non-international armed conflicts. Although these principles and prohibitions were initially deliberately omitted in AP II, ${ }^{181}$ the same calculations as during international armed conflicts have to be made when using particular weaponry in armed conflicts of a non-international character. In this regard, the ICTY in its Tadić case brought solace: "Indeed, elementary considerations of humanity and common sense make it preposterous that the use by States of weapons prohibited in armed conflicts between themselves be allowed when States try to put down rebellion by their own nationals on their own territory. What is inhumane, and consequently proscribed, in international wars cannot but be inhumane and inadmissible in civil strife."182

\section{$2.5 \quad$ Conclusion}

From this positivist perspective on the jurisdictional regimes of IHL and the principles of protection, it seems that these categorical imperatives conflict with the exigencies of military necessity and emergency situations. The structure of the legal arguments in IHL consists of these two opposing values, namely the communitarian (humanity) and sovereignty (necessity) ones. It is necessary to understand why these values have been formulated in those conflictual terms. In this regard, Chapter III in Part II will try to analyse a history of

\footnotetext{
180 Id., at 237 .

181 Id., at 48, 52 and 239.

182 Prosecutor v. Tadić, ICTY, Appeals Chamber, Decision on the Defence Motion for Interlocutory Appeal on Jurisdiction, 2 October 1995, Case No. IT-94-1-AR72, at www.icty .org, para. 119. (Last accessed on 15 February 2015)
} 
divide and rule against which the rules of armed conflict can be understood. A contextualisation of the narrative on the "Western" Self and its Other which have accompanied and informed the creation, interpretation and application of IHL might be useful to understand how the laws of war legitimise warring parties to have recourse to necessity in the first place. Both violence and the law seem to feed into each other's ambitions to assert their power.

Consequently, if any binding nature is to be expected from IHL in order to protect the victims of warfare, it appears that those hopes might be vain in reality because the structure of the legal arguments in IHL, as it stands, might never be fully conclusive when it comes to achieving those ends. Nonetheless, the laws of humanity which the Martens clause is referring to might be a possible guidance towards compliance of IHL. As Chapter VI in Part III will try to demonstrate, such humanitarian conscience might transcend the divisive nature of the structure of the legal arguments in IHL as possibly set up and influenced by the divisive narrative of the "Western" Self and its Other as will be examined in Chapter III. Such conscience might give an answer to this strategy to divide and rule over the legal protections as promised by humanitarian safeguards and foster that necessary change beyond the divisive structure of the legal arguments in IHL, so IHL could be truly humanitarian again in its spirit. 